\title{
The Relation Between Host TLR9 -1486T/C, rs187084 Gene Polymorphisms and Helicobacter pylori cagA, sodB, hsp60, and vacA Virulence Genes among Gastric Cancer Patients
}

\author{
AMIRA M. SULTAN ${ }^{1 *}$, RAGY SHENOUDA ${ }^{1}$, AHMAD M. SULTAN ${ }^{2}$, AHMED SHEHTA $^{2}$ and YASMIN NABIEL ${ }^{1}$ \\ ${ }^{1}$ Medical Microbiology and Immunology Department, Faculty of Medicine, Mansoura University, Mansoura, Egypt \\ ${ }^{2}$ Gastroenterology Surgical Center, Faculty of Medicine, Mansoura University, Mansoura, Egypt
}

Submitted 13 October 2021, accepted 19 December 2021, published online 27 February 2022

Abstract

To identify the associations between different genotypes of TLR9 -1486T/C (rs187084) with gastric cancer patients and reveal their relation to Helicobacter pylori virulence genes (cagA, sodB, hsp60 and $v a c A$ ). Patients with gastric cancer were recruited to our study, diagnosed both endoscopically and histopathologically. H. pylori were isolated from gastric samples by culture and PCR amplification of the $\operatorname{glm} M$ gene. Virulence genes $\operatorname{cag} A, \operatorname{sodB}, h s p 60$, and $v a c A$ were detected by multiplex PCR. Blood samples were used for genotyping of TLR9 -1486T/C (rs187084) by PCR-RFLP. Out of 132 patients with gastric cancer, $106(80.3 \%)$ were positive for H. pylori. A similar number of healthy participants was recruited as controls. The prevalence of $\operatorname{cag} A, \operatorname{sodB}, h s p 60$, and vacA genes among $H$. pylori was $90.6 \%, 70.8 \%, 83.0 \%$, and $95.3 \%$, respectively. The vacA gene alleles had a prevalence of $95.3 \%$ for $v a c A s 1 / s 2$, $52.8 \%$ for $v a c A m 1$, and $42.5 \%$ for vacAm2. The CC genotype of TLR9 -1486T/C had a significantly higher frequency in gastric cancer patients when compared to healthy participants $(p=0.045)$. Furthermore, the CC genotype demonstrated a significant association with $H$. pylori strains carrying $\operatorname{sodB}, h s p 60$, and vacAm 1 virulence genes ( $p=0.021, p=0.049$, and $p=0.048$ respectively). Patients with CC genotype of TLR9 -1486T/C (rs187084) might be at higher risk for the development of gastric cancer, and its co-existence with $H$. pylori strains carrying $s o d B, h s p 60$, or vacAm1 virulence genes might have a synergistic effect in the development of gastric cancer. Further studies on a wider scale are recommended.

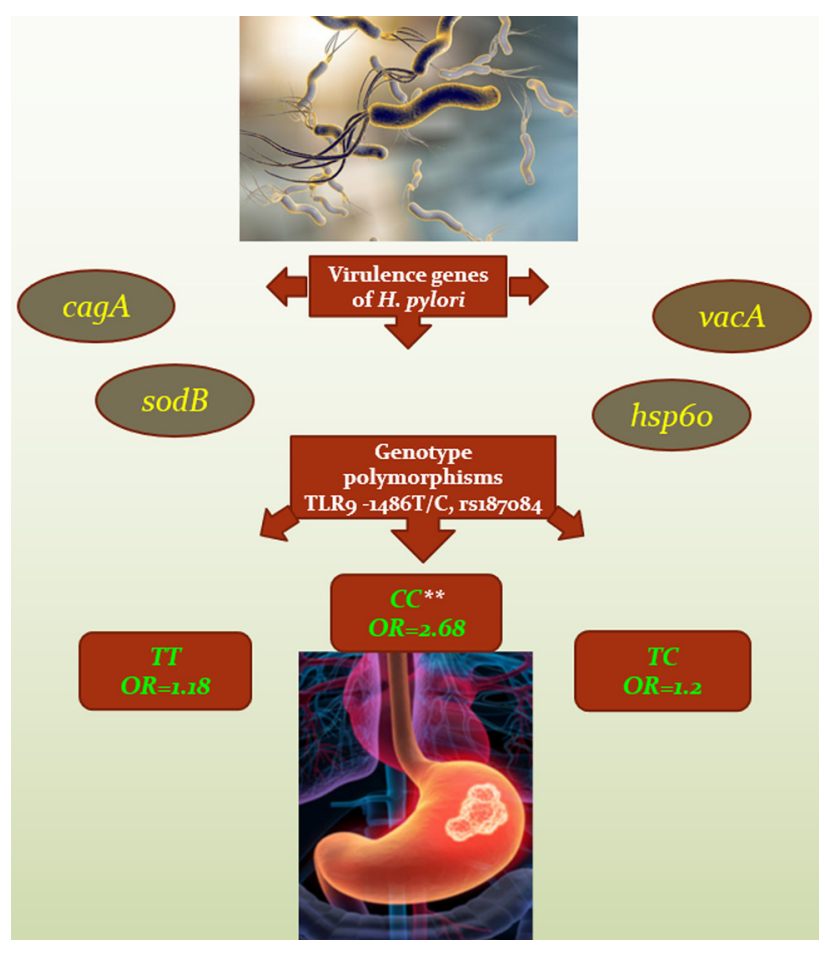

Ke y w o r d s: Helicobacter pylori, gastric cancer, gene polymorphism, Toll-like receptor-9, virulence genes

\section{Introduction}

Helicobacter pylori, described as spiral-shaped Gram-negative bacteria, can infect gastric mucosa in more than half of the population all over the world (Trindade et al. 2017). Such infection disturbs the homeostasis of the gastric mucosa and induces the release of inflammatory cytokines (Cadamuro et al. 2014). Subsequently, the high association was described between $H$. pylori infection and several gastric pathologies as chronic gastritis and gastric cancer (Polk and Peek 2010; Kao et al. 2016). Moreover, the WHO has classified $H$. pylori as a type one carcinogen because of its high association with gastric cancer (Santos et al.

\footnotetext{
* Corresponding author: A.M. Sultan, Medical Microbiology and Immunology Department, Faculty of Medicine, Mansoura University, Mansoura, Egypt; e-mail: amira110sultan@yahoo.com (C) 2022 Amira M. Sultan et al.

This work is licensed under the Creative Commons Attribution-NonCommercial-NoDerivatives 4.0 License (https://creativecommons. org/licenses/by-nc-nd/4.0/).
} 
2012). The development of such different gastric diseases has been linked to the interaction between H. pylori virulence factors, host genetics, immune responses, and environmental factors (Wroblewski et al. 2010; Bagheri et al. 2018).

Alterations in the host immune components, including Toll-like receptors (TLRs), through their prominent role in activating the innate and adaptive arms following infection, may influence the progress of the disease elicited by H. pylori (Wang et al. 2014; Song et al. 2018). These receptors are known as pattern recognition receptors as they identify the pathogen-associated molecular patterns (PAMPs) present in most pathogens (Varga and Peek 2017; Susi et al. 2019). During H. pylori infection, TLRs located on immune cells and local gastric epithelium identify various PAMPs present on that pathogen.

TLR9 detects unmethylated CpG oligonucleotides present abundantly in bacterial DNA (Fukata and Abreu 2008). As TLR9 is located inside the intracellular endosomes, its activation requires intracellular transfer of unmethylated $\mathrm{CpG}$ oligonucleotides through endocytosis (Füri et al. 2013). They are expressed by gastric epithelial cells and contribute considerably to immune recognition and signaling following $H$. pylori infection. Moreover, the proper TLRs activation is vital for gut protection and recovery from injury (Wang et al. 2013). Single nucleotide polymorphism (SNP) of TLR9 genes, such as TLR9-1486 TC (rs187084), can result in altered expression along with dysregulation of TLR9 signaling leading to unbalanced production of inflammatory cytokines with subsequent chronic inflammation, which promotes the development of gastric cancer (Wang et al. 2013). Such associations between TLR9 SNPs and increased risk to develop gastric cancer were previously reported (Wang et al. 2013; Susi et al. 2019).

Different virulence agents of $H$. pylori can be used as tools to predict the clinical outcomes of the infection (Polk and Peek 2010, Yamaoka and Graham 2014). The cytotoxin-associated gene $\mathrm{A}(\mathrm{Cag} \mathrm{A})$ is considered one of the main toxins of H.pylori (Ayala et al. 2014) that can cause morphological alterations in the host cell triggering cell differentiation and multiplication, which can help in the development of gastric cancer (Yong et al. 2015). The C-terminal region of CagA protein contains different Glu-Pro-Ile-Tyr-Ala (EPIYA) motifs that serve as phosphorylation sites for the protein. These EPIYA segments were classified into four types according to their flanking sequences: EPIYA-A, B, C, and D (Cristancho Liévano et al. 2018). The CagA oncogenic potential has been linked to the EPIYA motifs C and D (Ofori et al. 2019). This could be related to the affinity of the SHP2 phosphatase protein to join the EPIYA C and D motifs, which affect the carcinogenic ability of Helicobacter strains (Cristancho Liévano et al. 2018).
The vacuolating cytotoxin $(\mathrm{VacA})$ is another effective toxin produced by $H$. pylori strains and encoded by the $v a c A$ gene. It is a pore-inducing toxin that triggers apoptosis by inducing epithelial cellular vacuolation of the stomach (Palframan et al. 2012). The vacA gene has a mosaic structure with two main variation regions; the signal (s1 and s2), and the middle regions ( $\mathrm{m} 1$ and $\mathrm{m} 2$ ), which determine the toxin vacuolating activity (Ofori et al. 2019). The $\mathrm{s} 1 / \mathrm{m} 1$ and $\mathrm{s} 1 / \mathrm{m} 2$ genotypes are associated with high and moderate vacuolating activity, respectively. On the other hand, the vacuolating activity is absent in the $\mathrm{s} 2 / \mathrm{m} 2$ genotypes (Ofori et al. 2019). It was also reported that patients infected with vacAs $1 \mathrm{~m} 1$ positive $H$. pylori strains are more likely of developing the clinical disease (Miernyk et al. 2011; Ofori et al. 2019).

The superoxide dismutase enzyme (SOD), encoded by the $\operatorname{sod} B$ gene is an important bacterial enzyme that helps H. pylori strains to survive (Seyler et al. 2001; Ryberg et al. 2008). Furthermore, heat shock protein 60 (Hsp60) is a protein expressed abundantly by H.pylori that acts as a molecular chaperone, which guards unfolded proteins against acid accumulation (Mendoza et al. 2017).

The TLR9 plays a significant role in initiating the immune response following $H$. pylori infection. Hence, genetic variability in its promoter region as TLR9 -1486T/C (rs187084) SNP may alter the expression of this receptor, modify the response to $H$. pylori infection, and increase the risk of gastric cancer. The outcome of $H$. pylori infection is considerably affected by the interactions between bacterial virulence factors and the host immune responses. Therefore, the aim of this study was to identify the associations between different genotypes of TLR9 -1486T/C (rs187084) with gastric cancer patients and reveal their relation to $H$. pylori virulence genes (cagA, sodB, hsp60, and vacA).

\section{Experimental}

\section{Materials and Methods}

Patients selection. This study was conducted over 15 months (from December 2019 to February 2021). We have recruited 132 patients with gastric cancer at the Gastro-Enterology Surgical Center, Mansoura University, Egypt. They initially presented with gastric symptoms confirmed endoscopically and histopathologically to be gastric cancer. The control group included healthy participants who presented with gastric symptoms and proved to be free of any gastric pathology by histopathology and negative for H.pylori by microbiological processing of the biopsy samples. All the participants' epidemiological and clinical data were gathered from medical records. In addition, clinicians have medically interviewed all subjects. 
We have excluded any participant who fulfilled one or more of the set exclusion criteria: the previous gastric surgery and the use of anti-H. pylori eradication therapy, antibiotics, anti-inflammatory agents, proton pump inhibitors, chemotherapeutic drugs, or radiotherapy within one month before the endoscopy procedure.

Samples collection. A total of 238 stomach biopsies (each of size of $5 \mathrm{~mm} \times 5 \mathrm{~mm}$ ) were collected by clinicians during the performance of diagnostic gastric endoscopy procedures. The obtained biopsies were stored on ice and immediately transferred to the Medical Microbiology and Immunology Department, Mansoura University, Egypt, for further processing.

A peripheral blood sample of $10 \mathrm{ml}$ was collected under complete aseptic precautions from each study participant for investigating TLR9 gene polymorphisms (TLR9 -1486T/C, rs187084 SNPs).

Isolation of $\boldsymbol{H}$. pylori from gastric tissue samples. The collected biopsies were inoculated in sterile tubes with brain heart infusion (BHI) broth (Oxoid-UK), and then homogenized by a scalpel on a sterile slide. Homogenized samples were cultured on Colombia agar (Oxoid-UK) plates containing 10\% of freshly defibrinated sheep's blood. Besides, plates were supplemented with amphotericin B $(4 \mathrm{mg} / \mathrm{l})$, vancomycin $(10 \mathrm{mg} / \mathrm{l})$, polymyxin $B(10 \mathrm{mg} / \mathrm{l})$, and trimethoprim $(5 \mathrm{mg} / \mathrm{l})$ antibiotics (Oxoid-UK). Cultured plates were incubated under microaerophilic circumstances (Campy pack systems, BBL, Cockeysville, Maryland, USA) at $37^{\circ} \mathrm{C}$ for three days (Adinortey et al. 2018).

After three days, culture plates were examined for colonies where $H$. pylori isolates were identified by hav- ing small, translucent, and round colonies. Further recognition of $H$. pylori isolates was conducted by microscopic examination by seeing curved-shaped bacteria along with Gram-stained films followed by biochemical reactions (positive catalase, urease, and oxidase). Suspensions of $H$. pylori strains were prepared using BHI broth supplemented with $20 \%$ glycerol and then kept at $-20^{\circ} \mathrm{C}$ for further analysis (Idowu et al. 2019).

Molecular confirmation of isolated H.pylori strains through amplification of the $\operatorname{glm} M$ gene. Whole genomic DNA was obtained from cultured isolates using (QIAamp DNA Mini Kit; Qiagen, Hilden, Germany), in line with the provider's rules, then the resulted DNA was kept $-20^{\circ} \mathrm{C}$ until further completing of laboratory work.

The set of primers used to amplify the targeted gene was mentioned in Table I (Santos et al. 2012). The PCR was carried out using a master mix (Fermentas, Germany) that included $4 \mathrm{mM} \mathrm{MgCl}, 0.4 \mathrm{mM}$ of each $\mathrm{dNTP}$, and $0.05 \mathrm{U} / \mu \mathrm{l} \mathrm{Taq}$ DNA polymerase. In addition, $10 \mathrm{pmol}$ of each primer and $0.5 \mu \mathrm{g}$ of template DNA were included in the reaction mixture $(25 \mu \mathrm{l})$ (Menoni et al. 2013).

For amplification of the glmM gene, the PCR program started by an initial denaturation at $94^{\circ} \mathrm{C}$ for five minutes, then 40 cycles of denaturation for sixty seconds at $94^{\circ} \mathrm{C}$, annealing for ninety seconds at $55^{\circ} \mathrm{C}$, and extension for 120 seconds at $72^{\circ} \mathrm{C}$. The final extension was performed at $72^{\circ} \mathrm{C}$ for seven minutes (Menoni et al. 2013).

Molecular detection of $\operatorname{cag} A, \operatorname{sod} B, h s p 60$, and $v a c A$ virulence genes of $H$.pylori using multiplex PCR.

Table I

Sequences of primer sets used.

\begin{tabular}{|c|c|c|c|}
\hline $\begin{array}{l}\text { Gene } \\
\text { targeted }\end{array}$ & Sequence & $\begin{array}{l}\text { Size of amplified } \\
\text { product (bp) }\end{array}$ & Ref \\
\hline$g \operatorname{lm} M$ & $\begin{array}{l}\text { F: 5'AAGCTTTTAGGGGTGTTAGGGGTTT-3' } \\
\text { R: 5'-AAGCTTACTTTCTAACACTAACGC-3' }\end{array}$ & 294 & Santos et al. 2012 \\
\hline $\operatorname{cag} A$ & $\begin{array}{l}\text { F: 5'-GATAACAGGCAAGCTTTTGAGG-3' } \\
\text { R: 5'-CTGCAAAAGATTGTTTGGCAG-3' }\end{array}$ & 349 & Amin et al. 2019 \\
\hline $\operatorname{sod} B$ & $\begin{array}{l}\text { F: 5'-GCCCTGTGGCGTTTGATTTCC-3' } \\
\text { R: 5'-CATGCTCCCACACATCCACC-3' }\end{array}$ & 425 & Ryberg et al. 2008 \\
\hline hsp60 & $\begin{array}{l}\text { F: 5'-GCTCCAAGCATCACCAAAGACG-3' } \\
\text { R: 5'-GCGGTTTGCCCTCTTTCATGG-3' }\end{array}$ & 603 & Ryberg et al. 2008 \\
\hline$v a c A$ & $\begin{array}{l}\text { F: 5'-CAATCGTGTGGGTTCTGGAGC-3' } \\
\text { R: 5'-GCCGATATGCAAATGAGCCGC-3' }\end{array}$ & 678 & Ryberg et al. 2008 \\
\hline $\operatorname{vac} A s 1 / s 2$ & $\begin{array}{l}\text { F: 5'-ATGGAAATACAACAAACACAC-3' } \\
\text { R: 5'-CTGCTTGAATGCGCCAAAC-3' }\end{array}$ & 259 & Harrison et al. 2017 \\
\hline vacAm1 & $\begin{array}{l}\text { F: 5'-GGTCAAAATGCGGTCATGG-3' } \\
\text { R: 5'-CCATTGGTACCTGTAGAAAC-3' }\end{array}$ & 290 & Harrison et al. 2017 \\
\hline vacAm2 & $\begin{array}{l}\text { F: 5'-CATAACTAGCGCCTTGCAC-3' } \\
\text { R: 5'-GGAGCCCCAGGAAACATTG-3' }\end{array}$ & 352 & Harrison et al. 2017 \\
\hline $\begin{array}{l}\text { TLR9-1486T/C, } \\
\text { rs187084 }\end{array}$ & $\begin{array}{l}\text { 5'-TTCATTCATTCAGCCTTCACTCA-3' } \\
\text { 5'-GAGTCAAAGCCACAGTCCACA-3' }\end{array}$ & 490 & Roszak et al. 2012 \\
\hline
\end{tabular}


Multiplex PCR was undertaken following the coming steps simultaneously: beginning with incubation for 5 minutes at $95^{\circ} \mathrm{C}$; then 34 cycles consisted of one minute at $94^{\circ} \mathrm{C}$, then another one minute for primer annealing at $55^{\circ} \mathrm{C}$, followed by extension for 60 seconds at $72^{\circ} \mathrm{C}$; to be finished with the final extension step at $72^{\circ} \mathrm{C}$ for ten minutes (Amin et al. 2019). The reaction volume was $25 \mu \mathrm{l}$ and consisted of a PCR master mix (Fermentas, Germany) that included $4 \mathrm{mM} \mathrm{MgCl}, 0.4 \mathrm{mM}$ of each $\mathrm{dNTP}$, and $0.05 \mathrm{U} / \mu \mathrm{l}$ Taq DNA polymerase. Besides, $0.5 \mu \mathrm{g}$ of DNA and $10 \mathrm{pmol}$ of each primer were added. PCR products were then electrophoresed (Farshad et al. 2007). The reference strain (ATCC26695) was used as a positive control (Ryberg et al. 2008). Primer sets used were supplemented in Table I.

Molecular detection of different $v a c A$ gene alleles in vacA-positive H. pylori isolates (vacAs1/s2,vacAm1, and vacAm2). PCR was conducted by applying the following cycling parameters - first: $95^{\circ} \mathrm{C}$ for 5 minutes; second: 35 cycles $\left(95^{\circ} \mathrm{C}\right.$ for 30 seconds, $54^{\circ} \mathrm{C}$ for $30 \mathrm{sec}-$ onds and $72^{\circ} \mathrm{C}$ for 16,18 , and 21 seconds respectively according to the required allele to be amplified (vacAs1/ $s 2, v a c A m 1$ and $v a c A m 2)$ ). Then final extension was at $72^{\circ} \mathrm{C}$ for 10 minutes (Harrison et al. 2017). Sets of primers used were listed in Table I.

Genotyping of TLR9 - 1486T/C, rs187084 polymorphisms by PCR-RFLP. Genomic DNA was extracted from the obtained buffy coat (leukocyte-enriched fraction of whole blood) using Gene JET Whole Blood Genomic DNA purification Mini kit (Fermentas Life Sciences, Canada) according to provider's guidelines then exposed to PCR-RFLP. Blood samples were subjected to centrifugation at $2,500 \times g$ for 10 minutes to release three layers: the upper transparent layer containing plasma, the intermediate buffy coat, and the bottom layer of concentrated erythrocytes.

PCR reaction was run with thermal cycling conditions of 4 minutes at $95^{\circ} \mathrm{C}$ then 35 cycles each starting with 30 seconds at $95^{\circ} \mathrm{C}$ followed by 20 seconds at $60^{\circ} \mathrm{C}$, and 30 seconds at $72^{\circ} \mathrm{C}$ to be ended with final extension for 5 minutes at $72^{\circ} \mathrm{C}$ to produce a DNA piece of $490 \mathrm{bp}$ (Paradowska et al. 2016). The primers used were illustrated in Table I (Roszak et al. 2012).

Then the DNA products were digested using AflII restriction enzyme (Thermo Scientific, EU, Lithuania) by incubation for three hours at $37^{\circ} \mathrm{C}$ to yield one of three variants: two fragments of $192 \mathrm{bp}$, and $327 \mathrm{bp}$ that indicated TT allele, or three fragments of $192 \mathrm{bp}$, $327 \mathrm{bp}$, and $490 \mathrm{bp}$ that proved the presence of TC allele or an intact PCR fragment of $490 \mathrm{bp}$ indicating the presence of CC allele (Paradowska et al. 2016).

Statistical analysis. The data obtained were evaluated by the computer program SPSS (Statistical package for social science) version 22.0. Descriptive items were shown as means \pm standard deviation (SD) or frequency (number-percent). $p$-Values less than 0.05 were significant. The relation between genotypes and the risk of gastric cancer was detected by calculating the odd ratios (ORs) and 95\% confidence interval (CIs). We applied Hardy-Weinberg equilibrium to compare genotype frequencies we observed to the expected ones in studied healthy control. The relation between the virulence genes of $H$. pylori and TLR9 -1486T/C, rs187084 genotypes in gastric cancer patients was identified using chi-square test.

\section{Results}

This study included 106 subjects with gastric cancer and positive for $H$. pylori infection. A similar number of 106 subjects free of any gastric pathology and negative for $H$. pylori infection were recruited as a control group. No significant difference was found between both groups in both age and sex, as shown in Table II. Gastric cancer lesions were classified according to the histopathologi-

Table II

Demographic and histopathological data of the subjects included in the study.

\begin{tabular}{|l|c|c|c|}
\hline \multicolumn{1}{|c|}{ Variable } & $\begin{array}{c}\text { Gastric cancer } \\
\text { patients }\end{array}$ & $\begin{array}{c}\text { Healthy study } \\
\text { participants }\end{array}$ & $p$-value \\
\hline \multicolumn{4}{|c|}{ Age } \\
\hline Years (mean \pm SD) & $56.55 \pm 8.63$ & $53.27 \pm 8.55$ & 0.93 \\
\hline \multicolumn{4}{|c|}{ Sex } \\
\cline { 1 - 2 } Male & $63(59.4)$ & $59(55.7 \%)$ & 0.76 \\
\hline Female & $43(40.6 \%)$ & $47(44.3 \%)$ & \\
\hline \multicolumn{4}{|c|}{ Differentiation of the tumor } \\
\cline { 1 - 2 } Well differentiated tumor & $16(15.1 \%)$ & \multirow{2}{*}{ NA } & \\
\cline { 1 - 2 } Moderately differentiated tumor & $35(33.0 \%)$ & \\
\cline { 1 - 2 } Poorly differentiated tumor & $55(51.9 \%)$ & \\
\hline
\end{tabular}

Values are given as mean $\pm \mathrm{SD}$, or number (percentage)

NA - Not applicable 
Table III

Distribution of $H$. pylori among gastric tissue samples in studied gastric cancer patients.

\begin{tabular}{|l|c|c|c|}
\hline & Number & $\%$ & $p$-value \\
\hline Positive & 106 & 80.3 & \multirow{2}{*}{$0.000^{*}$} \\
\cline { 1 - 3 } Negative & 26 & 19.7 & \\
\hline Total & 132 & $100 \%$ & \\
\hline
\end{tabular}

* - statistically significant

Table IV

Distribution of virulence genes in H.pylori strains isolated from gastric cancer patients.

\begin{tabular}{|c|c|c|c|}
\hline Virulence gene & $\mathrm{N}=106$ & $\%$ & $p$-value \\
\hline \multicolumn{4}{|c|}{$\operatorname{cag} A$} \\
\hline Positive & 96 & 90.6 & \multirow{2}{*}{$0.000^{\star}$} \\
\hline Negative & 10 & 9.4 & \\
\hline \multicolumn{4}{|c|}{$\operatorname{sod} B$} \\
\hline Positive & 75 & 70.8 & \multirow{2}{*}{$0.000^{\star}$} \\
\hline Negative & 31 & 29.2 & \\
\hline \multicolumn{4}{|c|}{ hsp60 } \\
\hline Positive & 88 & 83.0 & \multirow{2}{*}{$0.000^{*}$} \\
\hline Negative & 18 & 17.0 & \\
\hline \multicolumn{4}{|c|}{ vacA } \\
\hline Positive & 101 & 95.3 & \multirow{2}{*}{$0.000^{*}$} \\
\hline Negative & 5 & 4.7 & \\
\hline \multicolumn{4}{|c|}{ vacAs1/s2 } \\
\hline Positive & 101 & 95.3 & \multirow{2}{*}{$0.000^{\star}$} \\
\hline Negative & 5 & 4.7 & \\
\hline \multicolumn{4}{|c|}{ vacAm1 } \\
\hline Positive & 56 & 52.8 & \multirow{2}{*}{0.56} \\
\hline Negative & 50 & 47.2 & \\
\hline \multicolumn{4}{|c|}{ vacAm2 } \\
\hline Positive & 45 & 42.5 & \multirow{2}{*}{0.12} \\
\hline Negative & 61 & 57.5 & \\
\hline
\end{tabular}

* - statistically significant

cal examination into well-differentiated tumors (15.1\%), moderately differentiated tumors $(33.0 \%)$, and poorly differentiated tumors (51.9\%) (Table II).
Of the 132 gastric cancer patients, 106 (80.3\%) gave positive results for $H$. pylori by both culture and PCR, whereas $26(19.7 \%)$ were negative. The results were statically significant $(p$-value $=0.000)($ Table III). The multiplex PCR revealed that the prevalence of cagA, sodB, hsp60, and vacA genes among the isolated H. pylori strains were $90.6 \%, 70.8 \%, 83.0 \%$, and $95.3 \%$, respectively. Regarding the vacA gene alleles, they had a prevalence of $95.3 \%$ for $v a c A s 1 / s 2,52.8 \%$ for $v a c A m 1$, and $42.5 \%$ for vacAm2 (Table IV).

We screened both the case and control groups for TLR9 $-1486 \mathrm{~T} / \mathrm{C}$, rs 187084 polymorphism by PCRRFLP. The obtained frequencies of genotypes of TLR9 $-1486 \mathrm{~T} / \mathrm{C}, \mathrm{rs} 187084$ in the healthy group were all on line with Hardy-Weinberg equilibrium. In gastric cancer patients, the frequencies of $\mathrm{T}$ and $\mathrm{C}$ alleles were $72(34.0 \%)$ and $140(66.0 \%)$, respectively, whereas in the control group, the $\mathrm{T}$ allele frequency was 122 (57.5\%), and the $\mathrm{C}$ allele frequency was 90 (42.5\%). We found that the frequency of the $\mathrm{C}$ allele in gastric cancer patients was significantly higher than in the control group ( $p=0.047)$. The frequency of CC genotype in gastric cancer patients $(52.8 \%)$ was significantly higher than the control group (22.6\%) with a $p$-value of 0.045 , whereas both TT and TC genotypes were not, as they recorded $p$-values of 0.73 and 0.68 , respectively as demonstrated in Table V.

The CC genotype of TLR9 -1486T/C, rs187084, when compared to TT + TC genotypes, demonstrated a significant relation with $H$.pylori strains carrying the $\operatorname{sod} B, h s p 60$ or $v a c A m 1$ virulence genes $(p=0.021$, $p=0.049$ and $p=0.048$ respectively). None of the cagA, $v a c A, v a c A s 1 / s 2$, or vacAm2 genes showed a significant association to CC genotype ( $p=0.075, p=0.88, p=0.88$ and $p=0.81$, respectively) (Table VI).

\section{Discussion}

We have reported a prevalence of $H$. pylori of $80.3 \%$ in patients with gastric cancer that was in agreement with previous studies (Ang and Fock 2014; Park et al.

Table V

Distribution of genotypes of TLR9 -1486T/C, rs187084 polymorphism in studied groups.

\begin{tabular}{|c|c|c|c|c|c|c|c|c|}
\hline \multirow[t]{2}{*}{$\begin{array}{l}\text { Genotype } \\
\text { frequency }\end{array}$} & \multicolumn{2}{|c|}{$\begin{array}{c}\text { Healthy study } \\
\text { participants } \\
\mathrm{N}=106\end{array}$} & \multicolumn{2}{|c|}{$\begin{array}{c}\text { Gastric cancer } \\
\text { patients } \\
\mathrm{N}=106\end{array}$} & \multirow[t]{2}{*}{ OR } & \multirow[t]{2}{*}{$95 \%$ CI } & \multirow[t]{2}{*}{$X^{2}$} & \multirow[t]{2}{*}{$p$-value } \\
\hline & $\mathrm{N}$ & $\%$ & $\mathrm{~N}$ & $\%$ & & & & \\
\hline $\mathrm{TT}$ & 40 & 37.7 & 22 & 20.8 & 1.18 & $0.45-3.1$ & 0.12 & 0.73 \\
\hline TC & 42 & 39.6 & 28 & 26.4 & 1.2 & $0.49-2.88$ & 0.16 & 0.68 \\
\hline $\mathrm{CC}$ & 24 & 22.6 & 56 & 52.8 & 2.68 & $1.0-7.14$ & 4.03 & $0.045^{\star}$ \\
\hline
\end{tabular}

Genotype frequencies are presented in the form of absolute numbers with percentages OR - Odds ratio; CI - Confidence interval; * - statistically significant 
Table VI

The relation between virulence genes of $H$. pylori and TLR9 -1486T/C, rs187084 genotypes in gastric cancer patients.

\begin{tabular}{|l|c|c|c|c|l|}
\hline $\begin{array}{c}\text { TLR9-1486T/C, } \\
\text { rs187084 } \\
\text { genotype }\end{array}$ & \multicolumn{2}{|c|}{$\mathrm{N}=56$} & \multicolumn{2}{c|}{$\begin{array}{c}\text { TT }+\mathrm{TC} \\
\mathrm{N}=50\end{array}$} & \multirow{2}{*}{$p$-value } \\
\cline { 1 - 4 } Virulence gene & $\mathrm{N}$ & $\%$ & $\mathrm{~N}$ & $\%$ & \\
\hline cagA & 55 & 98.2 & 41 & 82.0 & 0.075 \\
\hline sodB & 53 & 94.6 & 22 & 44.0 & $0.021^{*}$ \\
\hline hsp60 & 53 & 94.6 & 35 & 70.0 & $0.049^{*}$ \\
\hline vacA & 54 & 96.4 & 47 & 94.0 & 0.88 \\
\hline vacAs1/s2 & 54 & 96.4 & 47 & 94.0 & 0.88 \\
\hline vacAm1 & 35 & 62.5 & 21 & 42.0 & $0.048^{*}$ \\
\hline vacAm2 & 19 & 33.9 & 26 & 52.0 & 0.81 \\
\hline
\end{tabular}

* - statistically significant

2018). A slightly lower prevalence of $H$. pylori at $74.2 \%$ has been reported by Wang and his colleagues (2013). Nevertheless, Ezzat et al. (2012) reported a 100\% prevalence of $H$. pylori infection in gastric cancer patients. Such differences in $H$. pylori prevalence can be attributed to the host immune response, bacterial virulence factors, and environmental elements (Ofori et al. 2019).

In our study, the prevalence of cagA in $H$. pylori strains was $90.6 \%$ that was nearly similar to previous reports from Vietnam at 95\% (Uchida et al. 2009), North America at 88\% (Yamaoka et al. 1999), and Sweden at $82 \%$ (Ryberg et al. 2008). In our study, the $v a c A$ gene was detected in most of the isolated $H$. pylori strains (95.3\%) consistent with other reports (Ezzat et al. 2012; Amin et al. 2019). Also, we have reported the prevalence of the vacAm1 allele at $52.8 \%$, which was higher than that of $v a c A m 2(42.5 \%)$. In line with our results, the vacAm1 allele is commoner in Northern Asia while the vacAm2 allele predominates in Southeast Asia, which has a lower incidence of gastric cancer (Yamaoka and Graham 2014). Similarly, it was suggested that patients infected with the vacAm1-positive $H$. pylori strains are at more risk for severe outcomes as gastric cancer than vacAm2 genotype-positive H. pylori strains (Yamaoka and Graham 2014; Idowu et al. 2019). We detected the $s o d B$ and $h s p 60$ genes in $70.8 \%$ and $83.0 \%$ of $H$. pylori strains, respectively, which was in line with Ryberg and his colleagues (2008).

TLR9 plays a vital role in recognizing $H$. pylori DNA and initiating immune responses (Wang et al. 2013). Rad and his colleagues (2009) reported that TLR9 recognition of $H$. pylori has resulted in proinflammatory responses. It was recently suggested that $H$. pylori could reduce the inflammatory response through TLR9, leading to persistent infection (Varga and Peek 2017). Besides, it was reported that $H$. pylori DNA triggered TLR9-dependent activation of NF-kB in human neutro- phils that increased IL-8 production, which can participate in gastric cancer development (Alvarez-Arellano et al. 2014). Interestingly, some studies have reported that H.pylori can induce TLR9 expression, resulting in stimulating cellular mitogen-activated protein kinases, which trigger angiogenesis and cellular invasion (Chang et al. 2005). Furthermore, TLR9 has been associated with the up-regulation of cyclooxygenase-2 in $H$. pylori-infected gastric mucosa, which was linked to gastric cancer (Fukata and Abreu 2008).

For TLR9 -1486T/C gene polymorphisms, we found that the frequency of CC genotype was significantly higher in gastric cancer patients than the control group ( $p$-value $=0.045)$. Also, the frequency of the $\mathrm{C}$ allele in gastric cancer patients was significantly higher than in the control group $(p=0.047)$. Our findings suggested that $\mathrm{C}$ allele might have a role in modifying the immune response to $\mathrm{H}$. pylori infection and subsequently promoting gastric carcinogenesis. In line with our findings, Wang and his colleagues (2013) reported that CC and TC genotypes of TLR9 -1486 and the C allele carriers were associated with a higher gastric cancer risk among the Chinese population. Meanwhile, Susi et al. (2019) reported an association between CT and TT genotypes and increased risk of gastric cancer among the Brazilian population. On the other hand, Liu et al. (2015) found no association between TLR9 -1486 T/C polymorphism and gastric cancer risk. These different findings can be attributed to racial differences, environmental factors, and diverse genetic backgrounds in various populations.

In a gene assay conducted by Tao et al. (2007), the C allele of TLR9 -1486T/C down-regulates the expression of TLR9, which leads to deficient immune recognition and signaling in response to $H$. pylori. Consequently, both innate and adaptive immune responses will be reduced, which favors the development of chronic gastritis. This state of chronic gastritis can promote the development of gastric cancer, which can explain our findings. In a more recent study, $\mathrm{Xu}$ and his colleagues (2018) have reported a significant association between the CC genotype of TLR9 -1486T/C and increased expression of TNF- $\alpha$ and IL- $1 \beta$ cytokines, affecting the infection outcome. Therefore, such SNP can modify the TLR9 expression, affect the pathogenesis of $H$. pylori infection and increase the risk of gastric cancer (Wang et al. 2013). Still, the precise mechanism by which this SNP affects the risk of $H$. pylori-induced gastric cancer has to be clarified in future studies.

Most studies have focused on either host or bacterial risk factors for developing gastric cancer; however, we explored the relationship between the studied virulence genes of H.pylori and genotypes of TLR9 $-1486 \mathrm{~T} / \mathrm{C}$ (rs187084) polymorphism in gastric cancer patients. Interestingly, our findings have shown that 
the CC genotype had a significantly higher frequency in gastric cancer patients than the control group and that the CC genotype is significantly associated with $H$. pylori strains to harbor the $\operatorname{sodB}, h s p 60$ or vacAm1 virulence genes. Our findings can help clinicians stratify patients according to their tendency to develop gastric cancer and plan strategies for eradicating H. pylori infection.

\section{Conclusions}

This study suggested that patients with CC genotype of TLR9 -1486T/C (rs187084) might be at higher risk for the development of gastric cancer. In addition, our results offered some evidence that the co-existence of CC genotype of TLR9 $-1486 \mathrm{~T} / \mathrm{C}$ and H.pylori strains to carry the $\operatorname{sodB}, h s p 60$ or $v a c A m 1$ virulence genes might have a synergistic effect promoting the development of gastric cancer. Our findings support the link between host genetics, bacterial virulence genes, and gastric cancer. However, further studies are recommended on a larger number of cases and in more diverse populations.

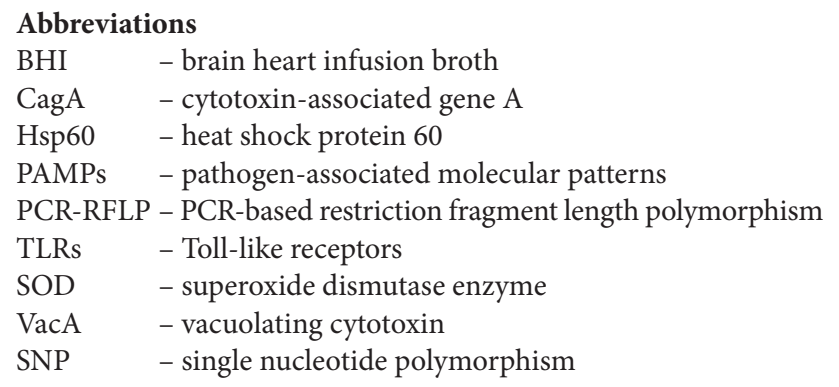

\section{Ethical statement}

This study was conducted in accordance with the Declaration of Helsinki, besides the national and institutional standards. Its protocol was approved by the Mansoura Faculty of Medicine Research Board (R.21.01.1165). Informed written consent was received from all participants included in the study.

\section{Author contributions}

Both Yasmin Nabiel and Amira Sultan were the creators of the research idea. They both shared in designing the protocol to be carried out, conducting the sample procedures, writing the manuscript, and analyzing the resulting data. Ragy Shenouda shared in processing the samples besides writing and revising the manuscript Both Ahmed M. Sultan and Ahmed Shehata shared in performing surgical maneuvers and collecting required samples from included study members.

\section{Conflict of interest}

The authors do not report any financial or personal connections with other persons or organizations, which might negatively affect the contents of this publication and/or claim authorship rights to this publication.

\section{Literature}

Adinortey MB, Ansah C, Adinortey CA, Bockarie AS, Morna MT, Amewowor DH. Isolation of Helicobacter pylori from gastric biopsy of dyspeptic patients in Ghana and in vitro preliminary assessment of the effect of Dissotis rotundifolia Extract on Its Growth. J Trop Med. 2018 Oct 31;2018:1-6.

https://doi.org/10.1155/2018/8071081

Alvarez-Arellano L, Cortés-Reynosa P, Sánchez-Zauco N, Salazar E, Torres J, Maldonado-Bernal C. TLR9 and NF- $\kappa B$ are partially involved in activation of human neutrophils by Helicobacter pylori and its purified DNA. PLoS One. 2014 Jul 2;9(7):e101342.

https://doi.org/10.1371/journal.pone.0101342

Amin M, Shayesteh AA, Serajian A. Concurrent detection of cagA, $v a c A, \operatorname{sod} B$ and $h s p 60$ virulence genes and their relationship with clinical outcomes of disease in Helicobacter pylori isolated strains of southwest of Iran. Iran J Microbiol. 2019 Aug 06;11(3):198-205. https://doi.org/10.18502/ijm.v11i3.1315

Ang TL, Fock KM. Clinical epidemiology of gastric cancer. Singapore Med J. 2014 Dec;55(12):621-628.

https://doi.org/10.11622/smedj.2014174

Ayala G, Escobedo-Hinojosa WI, de la Cruz-Herrera CF, Romero I.

Exploring alternative treatments for Helicobacter pylori infection.

World J Gastroenterol. 2014;20(6):1450-1469.

https://doi.org/10.3748/wjg.v20.i6.1450

Bagheri N, Razavi A, Pourgheysari B, Azadegan-Dehkordi F, Rahimian G, Pirayesh A, Shafigh M, Rafieian-Kopaei M, Fereidani R, Tahmasbi K, et al. Up-regulated Th17 cell function is associated with increased peptic ulcer disease in Helicobacter pylori -infection. Infect Genet Evol. 2018 Jun;60:117-125.

https://doi.org/10.1016/j.meegid.2018.02.020

Cadamuro ACT, Rossi AF, Maniezzo NM, Silva AE. Helicobacter pylori infection: host immune response, implications on gene expression and microRNAs. World J Gastroenterol. 2014;20(6):1424-1437. https://doi.org/10.3748/wjg.v20.i6.1424

Chang YJ, Wu MS, Lin JT, Chen CC. Helicobacter pylori-induced invasion and angiogenesis of gastric cells is mediated by cyclooxygenase-2 induction through TLR2/TLR9 and promoter regulation. J Immunol. 2005 Dec 15;175(12):8242-8252.

https://doi.org/10.4049/jimmunol.175.12.8242

Cristancho Liévano F, Trujillo Gama E, Bravo Hernández MM. Cag pathogenicity island of Helicobacter pylori and its association to preneoplastic lesion and gastric cancer. Rev Udca Actual Divulg Cient. 2018;21(2):309-318.

https://doi.org/10.31910/rudca.v21.n2.2018.972

Ezzat AHH, Ali MH, El-Seidi EA, Wali IE, Sedky NAER, Naguib SMM. Genotypic characterization of Helicobacter pylori isolates among Egyptian patients with upper gastrointestinal diseases. Chin-Ger J Clin Oncol. 2012 Jan;11(1):15-23.

https://doi.org/10.1007/s10330-011-0880-x

Farshad S, Japoni A, Alborzi A, Hosseini M. Restriction fragment length polymorphism of virulence genes $c a g A, v a c A$ and $u r e A B$ of Helicobacter pylori strains isolated from Iranian patients with gastric ulcer and nonulcer disease. Saudi Med J. 2007 Apr;28(4):529-534.

Fukata M, Abreu MT. Role of Toll-like receptors in gastrointestinal malignancies. Oncogene. 2008 Jan;27(2):234-243.

https://doi.org/10.1038/sj.onc.1210908

Füri I, Sipos F, Germann TM, Kalmár A, Tulassay Z, Molnár B, Müzes G. Epithelial Toll-like receptor 9 signaling in colorectal inflammation and cancer: clinico-pathogenic aspects. World J Gastroenterol. 2013;19(26):4119-4126.

https://doi.org/10.3748/wjg.v19.i26.4119

Harrison U, Fowora MA, Seriki AT, Loell E, Mueller S, UgoIjeh M, Onyekwere CA, Lesi OA, Otegbayo JA, Akere A, et al. Helicobacter pylori strains from a Nigerian cohort show divergent 
antibiotic resistance rates and a uniform pathogenicity profile. PLoS One. 2017 May 2;12(5):e0176454.

https://doi.org/10.1371/journal.pone.0176454

Idowu A, Mzukwa A, Harrison U, Palamides P, Haas R, Mbao M, Mamdoo R, Bolon J, Jolaiya T, Smith S, et al. Detection of Helicobacter pylori and its virulence genes ( $\operatorname{cag} A, \operatorname{dup} A$, and $v a c A)$ among patients with gastroduodenal diseases in Chris Hani Baragwanath Academic Hospital, South Africa. BMC Gastroenterol. 2019; 19(1):73. https://doi.org/10.1186/s12876-019-0986-0

Kao CY, Sheu BS, Wu JJ. Helicobacter pylori infection: an overview of bacterial virulence factors and pathogenesis. Biomed J. 2016 Feb;39(1):14-23. https://doi.org/10.1016/j.bj.2015.06.002

Liu S, Wang X, Shi Y, Han L, Zhao Z, Zhao C, Luo B. Toll-like receptor gene polymorphisms and susceptibility to Epstein-Barr virus-associated and -negative gastric carcinoma in Northern China. Saudi J Gastroenterol. 2015;21(2):95-103.

https://doi.org/10.4103/1319-3767.153832

Mendoza JA, Weinberger KK, Swan MJ. The Hsp60 protein of Helicobacter pylori displays chaperone activity under acidic conditions. Biochem Biophys Rep. 2017 Mar;9:95-99.

https://doi.org/10.1016/j.bbrep.2016.11.011

Menoni SMF, Bonon SHA, Zeitune JMR, Costa SCB. PCR-based detection and genotyping of Helicobacter pylori in endoscopic biopsy samples from Brazilian patients. Gastroenterol Res Pract. 2013;2013:1-8. https://doi.org/10.1155/2013/951034

Miernyk K, Morris J, Bruden D, McMahon B, Hurlburt D, Sacco F, Parkinson A, Hennessy T, Bruce M. Characterization of Helicobacter pylori cagA and vacA genotypes among Alaskans and their correlation with clinical disease. J Clin Microbiol. 2011 Sep; 49(9): 3114-3121. https://doi.org/10.1128/JCM.00469-11

Ofori EG, Adinortey CA, Bockarie AS, Kyei F, Tagoe EA, Adinortey MB. Helicobacter pylori infection, virulence genes' distribution and accompanying clinical outcomes: The West Africa situation. BioMed Res Int. 2019 Dec 10;2019:1-13.

https://doi.org/10.1155/2019/7312908

Palframan SL, Kwok T, Gabriel K. Vacuolating cytotoxin A (VacA), a key toxin for Helicobacter pylori pathogenesis. Front Cell Infect Microbiol. 2012;2:92. https://doi.org/10.3389/fcimb.2012.00092

Paradowska E, Jabłońska A, Studzińska M, Skowrońska K, Suski P, Wiśniewska-Ligier M, Woźniakowska-Gęsicka T, Nowakowska D, Gaj Z, Wilczyński J, et al. TLR9 -1486T/C and 2848C/T SNPs are associated with human cytomegalovirus infection in infants. PLoS One. 2016 Apr 22;11(4):e0154100.

https://doi.org/10.1371/journal.pone.0154100

Park J, Forman D, Waskito L, Yamaoka Y, Crabtree J. Epidemiology of Helicobacter pylori and CagA-positive infections and globa variations in gastric cancer. Toxins (Basel). 2018 Apr 19;10(4):163 https://doi.org/10.3390/toxins10040163

Polk DB, Peek RM Jr. Helicobacter pylori: gastric cancer and beyond. Nat Rev Cancer. 2010 Jun;10(6):403-414.

https://doi.org/10.1038/nrc2857

Rad R, Ballhorn W, Voland P, Eisenächer K, Mages J, Rad L, Ferstl R, Lang R, Wagner H, Schmid RM, et al. Extracellular and intracellular pattern recognition receptors cooperate in the recognition of Helicobacter pylori. Gastroenterology. 2009 Jun;136(7): 2247-2257. https://doi.org/10.1053/j.gastro.2009.02.066

Roszak A, Lianeri M, Sowińska A, Jagodziński PP. Involvement of toll-like receptor 9 polymorphism in cervical cancer development. Mol Biol Rep. 2012 Aug;39(8):8425-8430.

https://doi.org/10.1007/s11033-012-1695-8

Ryberg A, Borch K, Sun YQ, Monstein HJ. Concurrent genotyping of Helicobacter pylori virulence genes and human cytokine SNP sites using whole genome amplified DNA derived from minute amounts of gastric biopsy specimen DNA. BMC Microbiol. 2008 Dec;8(1):175. https://doi.org/10.1186/1471-2180-8-175

Santos JC, Ladeira MSP, Pedrazzoli J Jr, Ribeiro ML. Relationship of IL-1 and TNF-a polymorphisms with Helicobacter pylori in gastric diseases in a Brazilian population. Braz J Med Biol Res. 2012 Sep; 45(9):811-817. https://doi.org/10.1590/S0100-879X2012007500099 Seyler RW Jr, Olson JW, Maier RJ. Superoxide dismutase-deficient mutants of Helicobacter pylori are hypersensitive to oxidative stress and defective in host colonization. Infect Immun. 2001 Jun; 69(6):4034-4040. https://doi.org/10.1128/IAI.69.6.4034-4040.2001 Song M, Rabkin CS, Camargo MC. Gastric cancer: an evolving disease. Curr Treat Options Gastroenterol. 2018 Dec;16(4):561-569. https://doi.org/10.1007/s11938-018-0203-1

Susi MD, Lourenço CM, Rasmussen LT, Payão SLM, Rossi AFT, Silva AE, Oliveira-Cucolo JG. Toll-like receptor 9 polymorphisms and Helicobacter pylori influence gene expression and risk of gastric carcinogenesis in the Brazilian population. World J Gastrointest Oncol. 2019 Nov 15;11(11):998-1010.

https://doi.org/10.4251/wjgo.v11.i11.0000

Tao K, Fujii M, Tsukumo S, Maekawa Y, Kishihara K, Kimoto Y, Horiuchi T, Hisaeda H, Akira S, Kagami S, et al. Genetic variations of Toll-like receptor 9 predispose to systemic lupus erythematosus in Japanese population. Ann Rheum Dis. 2007 Feb 02;66(7):905-909. https://doi.org/10.1136/ard.2006.065961

Trindade LMDF, Menezes LBO, Souza Neta AM, Leite Rolemberg PC, Souza LD, Barreto IDC, Meurer L. Prevalence of Helicobacter pylori infection in samples of gastric biopsies. Gastroenterol Res. 2017;10(1):33-41. https://doi.org/10.14740/gr785w

Uchida T, Nguyen LT, Takayama A, Okimoto T, Kodama M, Murakami K, Matsuhisa T, Trinh TD, Ta L, Ho DQD, et al. Analysis of virulence factors of Helicobacter pylori isolated from a Vietnamese population. BMC Microbiol. 2009 Dec;9(1):175.

https://doi.org/10.1186/1471-2180-9-175

Varga MG, Peek RM. DNA Transfer and Toll-like receptor modulation by Helicobacter pylori. Curr Top Microbiol Immunol. 2017; 400:169-193. https://doi.org/10.1007/978-3-319-50520-68

Wang TR, Peng JC, Qiao YQ, Zhu MM, Zhao D, Shen J, Ran ZH. Helicobacter pylori regulates TLR4 and TLR9 during gastric carcinogenesis. Int J Clin Exp Pathol. 2014 Sep 15;7(10):6950-6955.

Wang X, Xue L, Yang Y, Xu L, Zhang G. TLR9 promoter polymorphism is associated with both an increased susceptibility to gastric carcinoma and poor prognosis. PLoS One. 2013 Jun 12;8(6):e65731. https://doi.org/10.1371/journal.pone.0065731

Wroblewski LE, Peek RM Jr, Wilson KT. Helicobacter pylori and gastric cancer: factors that modulate disease risk. Clin Microbiol Rev. 2010 Oct;23(4):713-739. https://doi.org/10.1128/CMR.00011-10

Xu F, Mai C, Zhu Q. Association of TLR-9 polymorphisms with the development of gastroduodenal ulcer: A hospital-based study in a Chinese cohort. Eur J Inflamm. 2018;16:1-9.

https://doi.org/10.1177/1721727X18757262

Yamaoka Y, Graham DY. Helicobacter pylori virulence and cancer pathogenesis. Future Oncol. 2014 Jun;10(8):1487-1500.

https://doi.org/10.2217/fon.14.29

Yamaoka Y, Kodama T, Gutierrez O, Kim JG, Kashima K, Graham DY. Relationship between Helicobacter pylori ice A, cagA, and $v a c A$ status and clinical outcome: studies in four different countries. J Clin Microbiol. 1999 Jul;37(7):2274-2279.

https://doi.org/10.1128/JCM.37.7.2274-2279.1999

Yong X, Tang B, Li BS, Xie R, Hu CJ, Luo G, Qin Y, Dong H, Yang SM. Helicobacter pylori virulence factor CagA promotes tumorigenesis of gastric cancer via multiple signaling pathways. Cell Commun Signal. 2015 Dec;13(1):30.

https://doi.org/10.1186/s12964-015-0111-0 